\title{
Analysis of Maritime Welding Policy in the Development of Global Hub Bandar Kayangan in North Lombok, Indonesia
}

\author{
Joko Susilo Raharjo, Ermaya Suradinata ${ }^{2}$, Sampara Lukman $^{3}$, Lalu Wildan ${ }^{4}$ \\ ${ }^{1234}$ Institut Pemerintahan Dalam Negeri, Indonesia \\ Email: joko68susilo@gmail.com
}

\begin{abstract}
This study aims to find the development of new models, using qualitative research designs with descriptive research types. The research informants were carried out by means of interviews, observations and literature studies as the techniques used in collecting data. While data reduction, data retrieval and conclusion drawing became the technical analysis of qualitative data used in this study. The analysis used in this study is an analysis of the implementation of the public policy model of Grindle (1980) and continued with analysis of ASOCA strategies. The results of this study are 1) Implementation of the global development policy Bandar Kayangan Hub can not be implemented optimally 2) Required strategies for problem solving in decision making. From the results of the analysis of the implementation of public policy based on Empirical Findings of ASOCA strategy analysis, a new concept of implementation strategy model 7 P JSRW was obtained, namely: 1) Government role (delegation process), 2) Zoning regulations, 3) Media role in making public opinion 4) The use of local labor, 5) The role of universities in printing experts, 6) Business actors (attracting investors) 7) Fair legal enforcement.
\end{abstract}

Keywords: Public Policy, Global Hub Development Planning, Maritime Axis.

\section{A. INTRODUCTION}

As the largest archipelago in the world, Indonesia has three quarters of its territory in the form of a sea with abundant natural resource wealth and environmental services (environmental services) are very large, the marine economy is a comparative advantage that can be transformed into competitive advantages and a source of new economic growth for Indonesia. Therefore, it is very appropriate and correct for President Jokowi and Vice President Jusuf Kalla to prioritize marine economic development to realize Indonesia as the World Maritime Axis (PMD) namely, a developed, prosperous, and sovereign Indonesia based on marine economy, security and maritime culture.

One form of implementation of PMD and seeing the potential of ALKI which is very large is with the construction of ports as a top priority. Seeing the importance of infrastructure development in the form of ports in Indonesia, West Nusa Tenggara Province is one of the regions whose economic growth is highly dependent on sea transportation. The efficient operation of the port is one of the top priority agenda of the Jokowi-JK cabinet work program. The direction of policy in the port sector emphasizes 
the arrangement of good port management with reference to regional development and economic improvement. This was also thought of by the West Nusa Tenggara Provincial Government in particular, as one of the efforts of the regional government in increasing economic growth and development. West Nusa Tenggara Province must be able to read this opportunity well, because it has a very strategic location that is located directly in the sea waters in the west and east, which has great potential for marine wealth in it which can be a source of income for the population from the fisheries sector, marine tourism and also its strategic position in ALKI II in the national and international shipping and trade flow. For this reason, the Province of West Nusa Tenggara is highly dependent on sea transportation, the operation of the port effectively is the ideals of the Province of West Nusa Tenggara, in order to realize the vision of development in the field of ports set by the Government.

Seeing this potential, the Provincial Government of West Nusa Tenggara then developed the Global Port Hub Global Development Plan which will be built in North Lombok Regency. The development of the Global Port of the port city of heaven can also have other positive effects, which can increase economic growth in the province of West Nusa Tenggara and the receipt of Regional Original Revenue (PAD) will increase significantly if the Port of Bandar Balikpapan is built, because the government will get revenue and activities from the port, in addition, the port will make the economy around the region be stretched. Economic growth and increased PAD will make the West Nusa Tenggara provincial government have more funds to finance the government and provide funds for the welfare of the population such as health, education, and others.

Seeing from the description above, this port development plan is the largest port development plan in Indonesia which will provide a positive impact also for the Indonesian State later. This great potential must be utilized by the government to increase economic growth and can be used for port master plans With the issuance of Government Regulation No. 13 of 2017 concerning (RTRWP) the Bandar Kayangan Global Hub Development which will be able to increase the activities of the trade industry, the synergy between planning, utilization and spatial control of the potential of environmentbased regions has not been running, it should immediately be implemented to increase state and regional income. The global design of the tire hub of heaven will be like the modern city of Dubai in Indonesia which can dock 500 meters long vessels with a depth of up to 35 meters with the presence of oil refineries in the city of heaven will be able to suck 200 to 300 thousand workers. Another problem is that, considering the use of potential in the maritime field is now a top priority and must synergize with other fields in national development. Because of the large number of marine resources that Indonesia has to utilize optimally and sustainably. However, in reality on the ground, Indonesia's marine development also has not been carried out in an integrated manner, where it is still sectoral, narrative, and fragmented, which often results in overlapping in its 
implementation and management. This can be observed with the absence of a grand design for the development of the Indonesian maritime sector agreed by all stakeholders involved. Therefore, to optimize the marine resources they have in order to accelerate national development so that an independent, developed, just and prosperous Indonesia is realized, a strong and appropriate Ocean Policy is needed.

In stages, the regional development policy of the Province of West Nusa Tenggara has been regulated in the Regional Spatial Plan, which is inaugurated by the Regional Regulation of the Province of West Nusa Tenggara. 3 of 2010 concerning the West Nusa Tenggara Provincial Spatial Plan (RTRWP) of West Nusa Tenggara, but there has not yet been a revision related to the spatial planning of the provinces and regencies of North Lombok so that investors are still waiting to invest in the global development of the Bandar Hub of the Nusa Tenggara Province. West.

The RTRWP emphasized that the city system in West Nusa Tenggara, that PKW aside from Praya, Sumbawa Besar and Raba, then PKW promotion was also set up in Gerung, Tanjung, Selong, Taliwang, Dompu, and Woha. Furthermore, to improve services up to the village level, then also established Local Activity Centers (PKL) in Sheets, Narmada, Kopang, Sengkol, Lucky, Bayan, Pamenang, Masbagik, Keruak, Labuhan Lombok, Poto Tano, Jereweh, Alas, Empang, Lunyuk, Lenangguar, Labangka, Calabai, Kempo, Hu'u, Sila, Tangga, Wawo, Wera and Sape.

To accelerate the development of the provincial economic growth, 12 KSPs (priority strategic areas) have been established, spread over 4 KSPs on Lombok Island and 8 KSPs on Sumbawa Island. Emphasis on economic development is prioritized in sectors: agriculture, mining, tourism, and fisheries. Bandar Kayangan City as a Global Hub must be able to play the role of: first, a regional service center for urban services; national; and between several countries. Second, it is expected to be able to serve energy needs especially to serve Eastern Indonesia. Third, it acts as a center for processing and assembling various goods and services to meet the needs of the "international market". Fourth, it acts as a center of attraction and service for tourism activities both on a national and international scale. Related to the role of Bandar Kayangan City as a Global Hub, it should be related within the framework of developing a "national logistics system" which is divided into local transportation networks, inter-island transportation networks, and global transportation networks and multimodal transportation. The creation of connectivity in Indonesia is not only based on geographic aspects, but the development of local connectivity and global connectivity needs to consider the sovereignty and resilience of the national economy. So that the concept of the front and inner regions is a strategic program in the logistics sector so that the competitiveness of local products in the domestic market can increase. In addition, this concept can be a driving force for the transformation of the Global Hub Port into a Logistics Port, which is a facility to facilitate the flow of goods to replace the port as a loading and unloading place. 
The establishment of "Global Connectivity" is expected to be able to connect the main centers of economic growth (National GateWay) to the International Hub port both in the western region of Indonesia and the eastern region of Indonesia, as well as between the International Hub port in Indonesia with the International Hub port in various countries spread over five continents in the world. In order to play a role as above, Bandar Kayangan City is planned to have three main components, namely: (1). main port (international global support). (2). Oil refineries and oil storage. (3). Manufacturing and assembly industries. The three main components are driving the economic activities of Bandar Kayangan to become and act as one of the "world cities". The next stage of Bandar Kayangan urban activities must be balanced by growth and development: (4). Trade activities are reflected in the form of a "central business district" (CBD) in the service capacity of national and international scale. (5). The center of tourism activities, national and foreign scale. Trade activities and tourism activities will work in synergy with the three main components so as to create an optimal urban growth multiplier of Bandar Kayangan. The results of the five urban components mentioned above will have an impact on the accelerated development of the Bandar Kayangan residential area, both the new settlement area and the existing settlement area. Thus, researchers are interested in researching the Maritime Axis Policy Analysis in the Global Hub Development Planning at Bandar Kayangan, North Lombok, West Nusa Tenggara Province.

Many researchers conduct research mainly in the heading of wisdom strategy (Yusuf et al, 2005; Suherman \& Daud, 2008; Supriatna et al., 2018; Teak, 2012; Suryadi, 2019), but the research will be conducted by researchers, in particular, The Maritime Axis Policy Analysis in the Bandar Kayangan Hub Global Development Plan has not been done by other researchers. The above is the basis for researchers conducting research with the first reason there has not been done by other researchers, especially research Analysis of Implementation of maritime axis policy in the development plan of the Global Hub Bandar Kayan-gan, West Nusa Tenggara Province. Second, this research is a reference to the central government and the Province of West Nusa Tenggara to build the Bandar Kayangan Global Hub in utilizing the geostrategic potential of the Indonesian archipelagic sea lanes as an engine for economic growth.

The purpose of this research is to analyze maritime police policies in the development plan of the North Hub Bandar Kayangan North Lombok port of West Nusa Tenggara Province, supporting factors and the readiness of maritime axis policy readiness in the development plan of the Bandar Hub Global Port of Bandar Kayangan, Nusa Tenggara Province West, and found a model of maritime shaft policy strategy in the development plan of the Global Hub Bandar Kayangan port of West Nusa Tenggara Province. 


\section{B. METHOD}

This study uses a qualitative research design with descriptive methods (Auerbach \& Silverstein, 2003; Creswell, 2013; Wolcott, 2009; Denzin \& Lin-coln, 2005). Data collection techniques used in this study include observation, in-depth interviews, and documentation studies. Determination of informants was carried out with a purposive sampling technique consisting of Deputy Minister of Maritime Affairs, Expert Staff of the Minister of Maritime Affairs, Head of West Nusa Tenggara Kesbangpol, Governor of West Nusa Tenggara, Head of West Nusa Tenggara BKPM, North Lombok Regent, Head of Regional Development Planning Agency West Nusa Tenggara Province, Head of Transportation Department of West Nusa Tenggara Province, and Global Hub Bandar Kayangan Designer, North Lombok. Analysis of research data was carried out with the model of Milles and Hubberman (1994) consisting of data reduction, data display and drawing conclusions and verification.

\section{RESULT AND DISCUSSION}

1. Maritime Axis Policy in the development of the Global Hub Bandar Kayangan, West Nusa Tenggara Province

Republic of Indonesia Government Regulation No.13 of 2017 concerning Amendment to Government Regulation No. 26 of 2008 concerning the National Spatial Planning, states that the North Lombok Region - Bandar Kayangan and its surroundings as a National Mainstay Area. This is a mandate that must be carried out immediately. The study for the selection of the location of Bandar Kayangan has actually been conducted since 2009, accompanied by various socialization and discussions in an effort to ensure the selection of suitable locations, especially in relation to Indonesia as the largest archipelagic country in the world, which has the potential to play a role as the world's maritime axis.

As the largest archipelago country in the world, Indonesia's position is very strategic, especially related to the development of industrial activities, world trade, and various other maritime activities. Indonesia is at the heart of the world's economic growth. The East Asia region has a rate of economic growth that is far above the average growth of the economies of other world regions. When the trend of long-term economic growth (1970-2000) in other regions of the world declined, the trend of economic growth in the East Asia region actually increased. As the center of gravity of the global economy, East Asia (including Southeast Asia) is inhabited by a large portion of the world's population. China has a population of 1.3 billion, while India has 1.2 billion people. The ASEAN region is home to 600 million people. Geographically, Indonesia is in the middle of the East Asia region which has enormous economic potential. 
In the aspect of global trade, today South to South trade, including transactions between India, China, and Indonesia, shows a rapid increase. Since 2008, the growth of developing countries' exports which has been driven by the demands of other developing countries has increased very significantly (contribution reached 54\%). This is very different from the condition in 1998, whose contribution was only $12 \%$. Growth, Transport from China, both exports and imports have a very important impact on the development of regional and global trade. Chinese imports increased sharply during and after the 2008 global economic crisis. In addition, large Chinese consumption can absorb large exports from countries around it, including Indonesia, placing Indonesia as the main power of countries in Southeast Asia. On the other hand, the consequences of the implementation of the ASEAN economic community and the presence of the ASEAN China Free Trade Area (ACFTA) require Indonesia to increase its competitiveness in order to get tangible benefits from the economic integration.

Geographical potential and prospects as a node of the world economy have underpinned national development policies, namely prioritizing Indonesia to become the World Maritime Axis. To achieve the role referred to above, the national development agenda will be focused on the 5 main pillars; first, that maritime culture for the Indonesian people must be rebuilt, secondly, preserve and preserve marine resources so that it has food sovereignty at sea, through strengthening the role of fishermen, third: prioritizing development in infrastructure and maritime affairs by building sea tolls, deep seaports, logistics, shipping industry and maritime tourism. Fourth, to support Indonesia's role in the maritime sector, maritime diplomacy is needed by building cooperation to overcome sources of conflict such as the establishment of national borders, fish theft, piracy, sea pollution, and the sea is a vehicle to unite various nations and countries. As for the fifth, in order to maintain and uphold the sovereignty of the State and nation, maritime power must be increased, so as to guarantee safety in shipping.

Accordingly, Law No.17 of 2007 concerning the National Long-Term Development Plan (RPJPN) mandates 9 tasks. The seventh mission is to develop the Indonesian archipelago into a modern, strong, self-reliant country, which fights for national interests. The Government's program to realize Indonesia as the world's maritime axis is not only to fulfill the law, even more than that, namely the prioritization of all national development programs.

Maritime Axis Policy in the development of the Bandar Kayan-gan Global Hub in West Nusa Tenggara Province has not been optimally implemented, with indicators:

a. The land to be used has no specific zoning in the planning of the Global Hub Bandar Kayangan Province of West Nusa Tenggara Province because there has been no revision related to the provincial spatial plan and North Lombok regency so that zoning cannot be determined yet.

b. There has not been good coordination between the central, provincial and North 
Lombok regencies in relation to the licensing of the Bandar Kayangan Global Hub Development.

c. Communication and synchronization to the vision of development and communication with the Ministry, related to efforts to change the status of the agricultural area and the residential population of fishermen into an industrial area have not been running.

d. Apparatus competence is still lacking and inadequate in supporting the wisdom of the Bandar Kayangan Global Hub development.

e. Communities in the areas affected by the policy have not fully agreed because there is an assumption that the policy will threaten their livelihoods as fishermen and agriculture.

f. The Bandar Kayangan Global Hub development planning process has not yet been fully supported by the central and regional governments even though this is the key to achieving Indonesia towards the global maritime axis.

\section{Analysis of Supporting and Inhibiting Factors Affecting the Maritime Axis Policy of the Bandar Kayangan Hub Global Development Plan}

The reality that occurs in the field when the policy has been determined by the policymaker, the process of implementing the policy is not as easy as imagined. Many things affect the implementation of the policy, so the policy to be implemented is very difficult to carry out even not at all.

In this regard, the researcher refers to two research concepts as an analysis of the factors that influence the implementation of the Bandar Kayangan Global Hub development policy in West Nusa Tenggara Province. First, Grindle's concept of Content of Policy (which encompasses, Interest affected; Type of benefit; Extent of change envisioned; Site of decision making; Program Implementors; and Resources committed) and Context of Implementation (encompasses, Power, interests, and strategy of actors involved; Institutions and regime characteristics; compliance and responsiveness). Secondly, Edwards III's concept of the influence of policy implementation, among others, Communication; Resource; Attitude (disposition); and bureaucratic structure.

The concept is the subject of the implementation of Bandar Kayangan Global Hub development policy in utilizing the potential of the Indonesian archipelagic sea lane in West Nusa Tenggara Province The analysis of researchers based on the Grindle concept of the factors influencing the implementation of the Bandar Kayangan Global Hub development in West Nusa Tenggara Province is explained complete as follows in accordance with the results of the interview summary, direct observation with resource persons.

Factors that become obstacles and supporters in wisdom the Maritime Axis of the Bandar Kayangan Global Hub development is: 
a. Lack of role and communication between related institutions in the development policy of the Bandar Global Hub. This phenomenon is seen from the lack of synergy between the Central Government, West Nusa Tenggara Provincial Government, North Lombok Regency Government which has hampered the direction of the development of the Bandar Kayangan Global Hub. In addition, the lack of planning related to the budget and insufficient resource support are other dominant obstacles. In addition, other dominant factors are the institutions and regime characteristics involved that still work partially, lack coordination, and have a strong sectoral ego.

b. Lack of available resources, this phenomenon can be seen from the lack of infrastructure, facilities, and lack of adequate quality and capability of human resources owned. These two factors are also evident from the failure of the Provincial Government, the Regional Government in the effort to free the conversion of the area into an industrial area where the Bandar Kayangan Global Hub Development site has been and there has been no follow up to accelerate the determination of the RTRWP and RTRWK.

c. Supporting factors have been planned since 2009 by the initiator of the Global Hub Bandar Kayangan Dr. Son Diamar and have entered the RTRWN.

d. A very strategic location in terms of geography and geopolitics as well as land that will be used in building a new city in Bandar Kayangan, North Lombok.

\section{Maritime Axis Policy Strategy Model for Global Development Hub Bandar Kayangan, North Lombok Regency, West Nusa Tenggara Province}

The strategy is the steps or efforts made in achieving a desired goal in an organization, in this case the steps or efforts taken by the Government of the Province of West Nusa Tenggara in implementing the policy of developing the Global Hub Bandar Kayan-gan government regulation Number 13 of 2017 concerning the National Spatial Planning (RTRWN). The existence of Bandar Kayangan will clearly have an impact on economic growth. The planned development of Kayangan Airport has become a necessity for the province and the community to support the loading and unloading activities of goods to meet the necessities of life in the West Nusa Tenggara Province, but the one that actively operates in the loading and unloading activities is the Sheet port located in West Lombok regency. Sheet Harbor seen from its location and feasibility is no longer feasible to operate for large vessels in the loading and unloading activities of goods. judging by the location it is still not possible to dock large vessels due to their shallow position. so ships that will enter and lean into the port of Sheesh, need to wait until the tide is rising. This certainly adds to the cost which results in high prices of goods. In addition, tourism vessels must use small vessels to go ashore at the entry point into the port. This is of course very disturbing to the activities of large vessels entering and exit- 
ing the port.

Seeing the many needs of the people of West Nusa Tenggara Province by relying on ports as cargo loading and unloading activities, the Provincial Government should make efforts or steps in meeting these needs, by reading the opportunities that exist to build new ports by looking at the potential and location of the port's position which is very strategic to meet the needs of people's lives and to boost economic growth and regional development in the province of West Nusa Tenggara. Even though now at Pelindo Port there is an expansion of the port expansion by Pelindo III but it still cannot accommodate large vessels that will enter according to the conditions of transportation and the development of the Sheet Port sea lane.

However, since the proposed development of the North Lombok Bandar Kayangan Global Hub and the issuance of Government Regulation on Spatial Planning No. 13 of 2017 until now it has not been going well. Whereas the development of the Bandar Kayangan Global Hub is the main priority scale of development for the North Lombok Regency Government, which is proposed to the Provincial Government so that it can be realized properly and can filter out large vessels passing through the crossing between countries through northern Lombok.

Analisis penelitian ini didasari dari bagaimana rancangan dan pelaksanaan terutama pada tahap identifikasi kebijaksanaan pembangunan Global Hub Bandar Kayangan dalam memanfaatkan potensi alur laut dua dan menuju poros maritim Dunia. Identifikasi tersebut secara komprehensif bersumber dari masing-masing faktor lingkungan, baik internal maupun eksternal dengan menggunakan klasifikasi berdasarkan unsur-unsur ASOCA. Analisis lingkungan merupakan analisis strategi yang bersifat internal untuk mengetahui dan mengidentifikasi serta merumuskan elemen-elemen yang menjadi faktor strengths (kekuatan), (ability) dan kecerdasan (agility).

The analysis of this research is based on how the design and implementation mainly in the identification stage of the Bandar Kayan-gan Global Hub development policy in exploiting the potential of the two sea lanes and towards the World maritime axis. The identification is comprehensively sourced from each of the environmental factors, both internal and external by using a classification based on ASOCA elements. Environmental analysis is an analysis of strategies that are internal to find out and identify and formulate the elements that become a factor of strengths (strength), (ability) and intelligence (agility).

Based on the results of the analysis conducted by researchers, produced a model that can achieve the objectives of the policy development process of the Glob-al Hub Bandar Kayangan Port, among others are as follows:

a. Land acquisition of protected forest areas, agricultural lands, and neo-service settlements is the first step to enter the next stage, such as conducting various studies and steps in implementing the Bandar Kayangan Global Hub development. 
b. The zoning concept that has been made by the Bandar Bandar Heaven initiator to support technically and the Bandar Kayangan Global Hub Development concept that will be built especially maximizing the use of the AL-KI II route can be realized early stages.

c. Building public opinion with various socialization and communication to the community, as an effort to increase understanding and support from the community itself, including also being able to encourage political will from various layers of Government institutions. The strategy can also provide reinforcement on the bureaucratic aspects and coordination with stakeholders and government organizations that intersect (from the district, provincial to central level) in the policy process of developing the Bandar Kayangan Global Hub especially to take care of such as location licensing.

d. It is hoped that the utilization and development of the local community workforce will provide full support to the government in assisting the Bandar Kayangan Global Hub development process.

e. Form a pattern of collaboration with universities and recruitment of experts who are considered to be able to help the development process of the Bandar Kayangan Global Hub both technically and substantially. This strategy can be used as an effort to improve inadequate human resources.

f. The plan that has been carried out by the initiator of the Bandar Kayangan Global Hub has made a master plan for the Bandar Kayangan Global Hub Development area. The plan includes a detailed engineering design (DED) explaining the technical implementation of the area, as material in the initial preparation of a feasibility study. Feasibility studies can be carried out such as conducting AMDAL studies (analysis of environmental impacts). The master plan details can also be used as a basis for efforts to ensure opportunities exist. These opportunities such as, implanting images (image), as well as persuading and attracting investors to invest their capital in the Bandar Kayangan Global Hub Development.

g. Cooperating with private parties that have been running with the Bandar Kayangan Global Hub Development Coordinator in development policies, in order to create prospective investment opportunities and increase investment promotion of port development with the aim of attracting resources. The encouragement can have an impact such as infrastructure development, funding, increased investment, employment, as well as increasing competition.

h. Applying the findings of the 7P model researcher (JSRW) in the process of accelerating towards the global maritime axis in the Bandar Kayangan Global Hub Development.

i. Give additional budget to the Ministry of Maritime Affairs to be more focused in policy towards the World Maritime Axis 


\section{CONCLUSION}

The implementation of the Maritime Axis policy in the development of the Bandar Kayangan Global Hub in West Nusa Tenggara Province is still not optimal. The inhibiting factor in the policy of the Maritime Axis of the Bandar Kayangan Global Hub development is the lack of roles and communication between related institutions and the lack of available resources. While supporting factors in the policy of the Maritime Axis of the Bandar Kayangan Global Hub development are already included in the RTRWN and a very strategic location from the geographical and geopolitical side as well as the land that will be used in developing new cities in Bandar Kayangan, North Lombok.

Models that can achieve the objectives of the policy process of developing the Bandar Kayangan Global Hub Port include, among others, the acquisition of protected forest areas, zoning concepts that have been made by the initiator, building public opinion, utilizing and developing the workforce of local communities, forming the pattern of cooperation with universities and the recruitment of experts, making master plans, collaborating with the private sector, applying the findings of the 7P model researcher (JSRW), and providing an additional budget to the Ministry of Maritime Affairs to focus more on policy towards the World Maritime Axis.

\section{REFERENCES}

1. Auerbach, C. Y. S., \& Silverstain, L. B. (2003). Qualitative Data. New York: New York University Press.

2. Creswell, J. W. (1994). Research Design: Qualitative dan Quantitative Approach. California: Sage Publications.

3. Denzin, N. K., \& Lincoln, Y. S. (2011). The Sage Handbook of Qualitative Research. Sage Publications.

4. Government Regulation Number 13 of 2017 concerning the Bandar Kayangan Hub Global Development (RTRWP).

5. Jati, R. (2012). Model Pengelolaan Wilayah Kepesisiran Secara Terpadu Untuk Pengembangan Sistem Pendukung Keputusan Perencanaan Pembangunan Kota Pesisir Berkelanjutan (Kasus Di Kota Semarang dan Kota Cilacap) (Doctoral dissertation, Universitas Gadjah Mada).

6. Regional Regulation of the Province of West Nusa Tenggara No. 3 of 2010 concerning the West Nusa Tenggara Provincial Spatial Plan (RTRWP).

7. Suherman, A., \& Dault, A. (2009). Dampak Sosial Ekonomi Pembangunan dan Pengembangan Pelabuhan Perikanan Nusantara (PPN) Pengambengan Jembrana Bali. Jurnal Saintek Perikanan, 4(2), 24-32. 
8. Supriatna, P., Jumiati, I. E., \& Waseh, H. (2018). Analisis Dampak Sosial Ekonomi Kebijakan Pembangunan Pelabuhan PT. Cemindo Gemilang Terhadap Kehidupan Masyarakat Desa Darmasari Kecamatan Bayah Kabupaten Lebakbanten (Doctoral dissertation, Universitas Sultan Ageng Tirtayasa).

9. Suryadi. (2019). Implementasi Kebijaksanaan Pembangunan Daerah Berbasis Kepulauan di Dukung Poros Maritim di Provinsi Maluku (Doctoral dissertation, IPDN).

10. Wolcott, H. F. (2009). Writing up Qualitative Research. Thousand Oaks, CA: Sage Publications.

11. Yusuf, H., Moedikdjo, K., Saeni, M. S., \& Nasution, L. I. (2005). Dampak pembangunan pelabuhan perikanan terhadap penyerapan tenaga kerja dan pendapatan masyarakat (studi kasus di Pelabuhan Perikanan Lempasing Bandar Lampung). Buletin Ekonomi Perikanan, 6(1), 57-64. 